UDC 378.14:81

MARYNA IKONNIKOVA, Doctor of Science in Pedagogy, Associate Professor, Associate Professor of the Department of Foreign Languages at Khmelnytskyi National University, Ukraine ORCID ID 0000-0002-0134-2331 ikonnikova@ukr.net

\title{
SOME GENERAL CHARACTERISTICS OF FUTURE PHILOLOGISTS' PROFESSIONAL TRAINING AT UKRAINIAN UNIVERSITIES
}

\author{
МАРИНА ІКОННІКОВА, доктор педагогічних наук, доиент, \\ дочент кафедри іноземних мов Хмельницького національного \\ університету, Украӥна
}

\section{ЗАГАЛЬНА ХАРАКТЕРИСТИКА ПРОФЕСІЙНОЇ ПІДГОТОВКИ МАЙБУТНІХ ФІЛОЛОГІВ В УНІВЕРСИТЕТАХ УКРАЇНИ}

У статті проаналізовано професійну підготовку майбутніх філологів у закладах вищої освіти України. Визначено та обгрунтовано зміст професійної підготовки філологів на прикладі спеціальності "Германські мови та літератури (переклад включно)" $з$ урахуванням нових нормативних вимог. Охарактеризовано найбільш ефективні форми, методи і технології організації освітньої діяльності майбутніх філологів. 3'ясовано складові професійної компетентності майбутніх фахівців германської філології. Проаналізовано процедури і заходи внутрішнього забезпечення якості вищої філологічної освіти. Обгрунтована у статті загальна характеристика професійної підготовки майбутніх філологів в університетах України засвідчила необхідність трансформації змісту підготовки, а також запровадження ефективних організаційних форм і методів навчання, що сприятиме розвитку суб'єкт-суб'єктної взаємодії в освітньому процесі, розвитку особистості, забезпеченню якості навчання.

Ключові слова: підготовка, освітні програми, організація, навчальна діяльність, зміст, форми, методи, технології, професійна компетентність.

The paper analyzes professional training of future philologists in higher education institutions in

(C) M. Ikonnikova
Ukraine. It determines and justifies the content of future philologists' professional training on the example of the degree programme on Germanic Languages and Literature (including Translation), taking into account the new regulatory requirements. It describes the most effective forms, methods and technologies of organizing educational activities of future philologists. It clarifies the components of professional competency of future specialists in Germanic philology. It specifies the procedures and measures for assuring the internal quality of philological education at higher education institutions. Some general characteristics of future philologists' professional training in higher education institutions in Ukraine, justified in the paper, have proved the need to update the content of such training and introduce effective organizational forms and methods of teaching and learning, which will promote the subject-subject interaction in the educational process, as well as contribute to personality development and assure the quality of education.

Key words: training, educational programs, organization, educational activity, content, forms, methods, technologies, professional competence.

The paper aims to disclose some general characteristics of future philologists' professional training at Ukrainian universities (on the example of the degree programme on Germanic Languages and Literature (including Translation)).

Problem statement. Professional training of philologists is a holistic, purposeful, dynamic and systematic process aimed at developing their values-based and professional orientations to perform professional functions efficiently. Modern challenges of linguistic globalization, strategic guidelines of the information space, as well as the rapid development of communication technologies in all sectors, have raised the attention to the quality of professional training of philologists, who have profound theoretical knowledge and practical skill, effectively apply communication strategies and tactics, employ languages while developing linguistic software, standardize and unify research and technology terminology, elaborate methods and technologies of automatic annotation, abstracting, machine translation, foreign literature.

Analysis of recent studies and publications. Over several decades, Ukrainian researchers have been studying the problem of professional training of philologists in the context of both Ukrainian and international experience. Different aspects of philological education have been covered by L. Bazyl, N. Bidiuk, S. Danyliuk, H. Klochek, O. Komochkova, N. Kolesnychenko, O. Martyniuk, L. Matsko, O. Rohulska, O. Semenoh, T. Symonenko, K. 
Skyba et al. Also, the views on methodological aspects of foreignlanguage training of philologists are important to this research (N. Bibik, L. Chernovatyi, O. Cherednychenko, M. Hasparov, L. Morska, S. Nikolaieva, I. Zadorozhna et al.).

Results. Such aspects as Ukraine's integration into the global economics, the expansion of international cooperation and the growth of international trade and diplomatic activity have caused the need for philologists with skills in foreign languages, communication and translation. The current changes in Ukraine's educational paradigm require that the content and organizational principles of professional training of philologists should follow a competency-based approach. However, knowledge of foreign languages is a basic but insufficient condition for professional competency of future philologists.

The analysis of regulatory documents indicates significant changes in the list of fields in professional training of various specialists at Ukrainian universities between 2010 and 2016. According to the order of the Ministry of Education and Science No 567 as of May 25, 2016 "On the Approval of the List of Specializations for Bachelor's and Master's Degrees in Philology (032)", there are the following specializations [7]:

035.01 - Ukrainian language and literature;

035.02 - Crimean Tatar language and literature;

035.03 - Slavic languages and literatures (including translation); 035.04 - Germanic languages and literature (including translation); 035.05 - Romance languages and literature (including translation); 035.06 - Oriental languages and literature (including translation); 035.07 - Finno-Ugrian languages and literatures (including translation);

035.08 - Classical languages and literatures (including translation); 035.09 - Folklore Studies; 035.10 - Applied Linguistics.

The analysis of the 2016-2017 admission campaign shows that these are the most popular specializations: 035.04 Germanic languages and literature (including translation); 035.05 Romance languages and literature (including translation); 035.06 Oriental languages and literature (including translation); $035.10 \quad$ Applied Linguistics. From 2006 to 2016 , the number of graduates by these specializations increased. The total number of graduates in this field was 4368 persons (bachelor's degree 2 412 persons, specialist degree 1436 persons, master's degree 520 persons) in 2006 and 5975 persons (bachelor's degree 3286 persons, specialist degree 1336 persons, master's degree 1353 persons) in 2016. Thus, growth dynamics is equal to $26,9 \%$ (Informatsiina systema "Konkurs", URL : http:// vstup.info). Over the last ten years, there has also been an increase in the number of applicants for foreign philology, especially in the fields of translation and oriental languages and literatures. Moreover, there is a clear tendency to switch to a twostage system of professional training for transfer students. Master programmes are of particular importance now.

In Ukraine, professional training of specialists is regulated by higher education standards. In 2017, the Ministry of Education and Science of Ukraine proposed new draft higher education standards, including for philologists. Higher education standards include general and professional competencies determining the specifics of philologists' training and expected learning outcomes; characterizing the knowledge, understanding and abilities students are expected to acquire after successful completion of a degree programme. Competencies and expected learning outcomes are consistent with each other and meet the descriptors of the National Qualifications Framework. Universities are entitled to compile the list of courses students need to master to acquire competencies (competences) defined by the standard. The compulsory content of degree programmes (minimum $35 \%$ ) includes those courses which ensure the achievement of learning outcomes defined by the standard. Universities can also indicate additional competencies and learning outcomes that correspond to the optional component of degree programmes (Proekty standartiv vyshchoi osvity, URL : http:// mon.gov.ua/activity/education/ reform a - os viti/n a u kovometodichna-rada-ministerstva/ proekti-standartiv-vishhoyiosviti.html.).

Thus, the main requirements set out in the standard involve skills and abilities meeting the concept of competency. The standard of a master's degree in Philology defines three vectors for developing professional competency in Masters in Philology: integral competency (ability to solve complex problems and tasks in the field of linguistics, literary studies, folklore studies and translation during professional activities or study, which involves conducting research / or presenting innovations and is characterized by uncertain conditions and requirements; general competencies (ability to communicate in the official language both verbally and in writing; ability to be critical and selfcritical; ability to find, process and analyze information from different sources; ability to identify, pose and solve problems; ability to work in a team and autonomously; ability to communicate in a foreign language; ability to appreciate and respect diversity and multiculturalism; abstract thinking, analysis and synthesis skills; ability to use information and communication technologies; ability to adapt and act in a new situation; ability to communicate with experts in other fields; ability to conduct research at an appropriate level; ability to generate new ideas (creativity); specialized (professional, subjectspecific) competencies (ability to navigate freely in different linguistic areas and schools; ability to comprehend the art of words as a system of systems, understand the development of literary criticism in Ukraine and abroad; ability to critically analyze the historical heritage and the latest achievements of philology; ability to analyze and structurize language and literary material, taking into account classical and modern methodological principles; ability to understand the methodological, organizational and legal framework required for the implementation of professional research, its presentation to the scientific community and the copyright of its results; ability to apply in-depth 
knowledge in certain philological specializations (linguistics, literary studies, folklore studies, translation studies, applied linguistics, literary criticism); ability to use specific terminology in the chosen field of philological research; ability to express opinions clearly, use elocution techniques: correct breathing, voice development, clear diction, correct pronunciation; ability to use expressive, emotional and logical linguistic means to achieve expected pragmatic results; ability to plan, organize, conduct and present applied research in philology; ability to plan, organize, conduct and present scientific theoretical and applied research in philology; ability to participate effectively and competently in various forms of scientific communication (conferences, roundtable conferences, discussions, scientific publications) in the field of philology; ability to generate new knowledge, ideas and concepts in philology). However, the analysis of degree programmes in Philology shows that certain competencies presented in a general functional aspect should be refined according to professional activities and tasks. The content of philological education is based on a competency-based approach and, unfortunately, does not fully reveal and reflect professional competencies of future philologists. Consequently, there is a certain imbalance in the competency competence format.

A study of different degree programmes reveals their disadvantages, including inconsistency between expected learning outcomes and practical professional activities of future philologists; a non-transparent structure and logic of the curriculum to students and teachers; an uncertain role of cycles of courses in the development of professional competences in graduates; students' lack of freedom in choosing, compared to universities; an insufficient justification of practical realization of independent work and research activities.

Undergraduate

degree programmes in Philology involve 4 years (240 ECTS). A minimum of 50\% of the degree programme should be aimed at developing general and subject-specific competencies defined by the standard. Subsequently, industrial and teaching placements should cover no less than $5 \%$ of the degree programme each. In Ukraine, graduate degree programmes can last for 1.5 or 2 years (90 ECTS taught Master's degrees; 120 ECTS research Master's degrees).

According to N. Kolesnychenko, the development of Romance and Germanic philologists' competitiveness is a specially organized process, caused by the complication and hierarchization of regulatory mechanisms of their vital activity, the internalization of external regulators and the evolvement of self-regulation and self-determination mechanisms under the influence of certain organizational and pedagogical conditions as external consequences. This process consists of target, basic and qualifying stages. Each stage, characterized by the importance of its results as integral characteristics of a competitive specialist in Romance and Germanic philology, should develop the qualities necessary for successful professional performance under the conditions of developing the market of intercultural communication, translation and educational services, taking into account individual opportunities and needs, as well as resources of educational and sociocultural systems (Kolesnychenko, 21014, p. 130).

The content of professional training of philologists includes compulsory and optional parts. The compulsory part should be cover at least $40 \%$ and no more than $60 \%$ of a total academic load. The teaching of humanities and basic courses aims to highlight relevant philosophical issues in various fields of scientific knowledge, thus greatly widening the professional outlook of future philologists. Professional courses provide students with the necessary knowledge of special fields and develop their translation skills. The optional part can be defined by universities for each degree programme. It contains optional courses chosen by universities (7-8 courses up to 20 credits), as well as optional courses chosen by students (6-7 courses up to 15 credits). The total volume of the optional part involves $25-35$ credits according to study duration. A large number of optional courses (usually low-credit courses up to 3 credits) is predetermined by the system of the educational process organization at Ukrainian universities, as well as the planning and distribution of study load. It must be noted that optionality can be formal in nature, which does not contribute to the individualization of the educational process, creating conditions for greater autonomy and freedom of choice. Therefore, the problem of choosing an educational trajectory for philologists requires comprehensive solutions at the national level. Indeed, master's degree programmes are insufficiently diversified, which hinders the development of the scientific potential in philologists.

The analysis of degree programmes in Translation proves the need to fundamentalize linguistic training, which involves providing systematic knowledge and metareflections and incorporates professional orientations in the content of academic courses. The fundamentality of professional training of future translators implies the completeness and depth of cultural, literary, linguistic and translation-related knowledge, skills and abilities to comprehend linguistic, literary and translationrelated concepts, taking into account the principles of dialogism, historicism, systematism and scientificity. Fundamental training of students involves their study of linguistic and translation-related courses ("The History of Translation", "General Linguistics", "Practical Course of Foreign Languages, "Translation Practice", "Practical Grammar", "Lexicology", "The Theory of Language Communication"), which are aimed at understanding translation as a means of communication, its social functions, the origin and patterns of historical development, as well as at mastering the language system as a means of developing translationrelated thinking. The study of these courses contributes to forming and developing professional competency in future translators, including their analytical, interpretative, linguistic, cultural, 
diagnostic and prognostic skills. These skills are manifested in philology students' ability and willingness to think creatively, prove, justify, find, select, analyze and interpret information from various sources, including electronic sources; deliver oral and written translation, taking into account structural, semantic, genrerelated, compositional, linguistic and stylistic features.

Such components of higher education standards as targets, values, content and results are implemented in the educational process through effective teaching forms, methods and technologies. An important aspect of this problem is the innovative modelling of forms and methods, depending on educational levels and individual characteristics of philology students.

Practical experience shows that the main organizational forms of professional training of future philologists at universities are: lectures (introductory lectures, informative lectures, summary lectures, systematic lectures, problematic lectures, review lectures); seminars (concretization and consolidation of scientific knowledge; generalization of scientific knowledge; systematization of scientific knowledge; specialized research seminars); practical classes and laboratory work; placement (industrial placement, teaching placement); summative assessment (pass-fail tests, examinations); subject-specific olympiads; group and individual consultations; final state certification (state exams, defence of theses (projects); independent work (reports, termpapers (projects). The following forms and methods of teaching are effective for future translators: lectures, mini-lectures, discussionoriented practical classes and seminars similar to professional activities in form and content; professionally motivated independent work, creative individual tasks, research activities; analytical, professionally important tasks (a linguistic analysis of original texts; translation analysis of original and translated texts), abstracted and full translation of original texts; creative and productive quasi- professional tasks (business and role-playing games, debates, discussions, conflict resolution, translation-related tasks), participation in educational and cultural events; advanced profession-oriented types of educational and cognitive activities overseas immersion experience, industrial placement, linguistic and translation practice with native speakers. Teaching methods mostly include verbal, explanatory-andillustrative, generic, problematic and research ones, given that professional training of future philologists is based on the principle of multi-structuralism, which consists of three sub-structures (thematic, activity-related and reflexive).

Also, practical training of future philologists involves writing tests, articles, abstracts, reviews on oral and written texts, essays, summaries; taking notes; doing crossword puzzles; participating in language games; preparing linguistic tasks, performing creative tasks (writing descriptions, sketches, landscape portraits, vernacular stories narratives); situational modelling; problembased tasks; independent work based on professional philological journals, broadcasts of radio and television, linguistic sites, electronic dictionaries, guides, web-sites of linguists; compiling one's electronic library; participating in volunteer translation activities.

The effective forms of developing efficient and creative thinking include integrating the theory acquired by philology students during lectures and mastering practical principles of applying this theory in the context of collective cognitive activity during seminars. It must be noted that seminars enable philology students to justify their views, lead discussions and dialogues and act as an opponent. One should pay particular attention to the study by O. Cherednychenko, who combines the necessary components of professional competency of interpreters and translators with the four main functions of translation in the modern world. He believes that the translator should have linguistic, cultural, stylistic and referential competences in a particular field, be able to resist the excessive influence of foreign languages, preserve the national cultural heritage, as well as develop and disseminate his or her native language (Cherednychenko, 2007, p. 25-27).

Depending on the goals, objectives and content, practical training of philology students encompasses different types of seminars with their specific structure and methodology. According to the nature of their organization, the most common types of seminars are introductory seminars; review seminars; self-organized seminars; seminars combined with individual work; seminars combined with group work; seminars in groups of choice; ideas generation; round-table conferences, debates, exhibitions; reflection; detailed conversations; reading with comments; problemsolving; industrial training.

In the context of European higher education standards and creditbased modular learning, theorists and practitioners especially focus on independent work, which implies reducing classroom workload. Independent work is aimed at consolidating knowledge and skills acquired during practical classes; expanding and deepening theoretical material; developing skills of independent work with literary sources, dictionaries; performing practical translationrelated tasks. Types of independent work depend on the specifics of the course and may include processing information obtained during hours of classroom work (lectures, practical classes); working with textbooks and lecture notes; studying particular topics or issues independently (brainstorming) and making relevant summaries; working with additional (monographs, scientific articles, Internet materials) and reference literature (dictionaries, encyclopedias, glossaries); performing creative writing tasks (presentations, reports, speeches, essays, answers to problematic questions, term-papers, master dissertations); performing individual tasks (analytical and research work, situational modelling); preparing visual aids (tables, diagrams, projects); gaining experience in translating during translation practice; participating in roleplaying and business games, 
training sessions; compiling glossaries of terms, concepts and categories of a particular topic or field; creating crosswords, charts and mind maps during practical lessons; engaging in independent work on the Internet (searching and processing information, organizing dialogues, creating thematical webpages); mastering machine translation and computer-assisted translation; working with electronic monolingual and multilingual dictionaries (ABBYY Lingvo, Yandex); using machine translation software (PROMT, Pragma, Language Master, Trados, WordFast, Google Translate); performing independent tasks using modern word processors (typing programmes, word processing, text editing programmes, spell check software, grammar check tools, terminology management FileMaker, LogiTerm, MultiTerm, Termex, TermStar).

Some scholars (O. Martyniuk, O. Rohulska, K. Skyba) believe that developing professional competency in translators should be aimed at performing the following functions: ensuring written and (or) oral, interlingual and intercultural communication in various (or specific) spheres of social activity; applying modern methods of collecting and processing information; using global information networks, automated search engines, electronic databases, glossaries and reference guides; conducting research in the field of professional activity. The following are important personal characteristics of translators: erudition; a well-developed culture of thinking; abilities to clearly and logically express oneself orally and (or) in writing and critically evaluate professional experience; organizational skills; self-study skills; analysis skills (Martyniuk, 2010; Rohulska, 2010; Skyba, 2010).

According to O. Popova, the traditional interactive forms of professional training of future translators are translation-related and speech training sessions (rapid response, rapid learning), roundtable discussions, translation arenas (discussing and identifying effective approaches to solving translationrelated problems), debates (learning to think logically and justify one's opinions, speak concisely and clearly if the interlocutor thinks differently), practical seminars (developing practical skills in oral and written translation). New interactive forms can involve business games (the ideas bank learning how to deal with nonstandard situations and speak impromptu), exhibitions and fairs of translation ideas (demonstrating knowledge and skills in the field of translation studies). They are also actualized by translation workshops or studios (a rational way to collectively solve translation-related problems through presenting the knowledge and skills in using translation tools and ICTs), symposiums of sinologisttranslators, creative hours ("The Pearls of Translation"; group work on the elaboration of methodical recommendations on mastering the theory and practice of translation in language pairs), employers' sessions ("Crewing Exams"; "Being on Trial at a Translation Agency"; "At a Travel Agency"); interactive communication with potential employers; promotion of professional knowledge, skills, abilities); alumni meetings ("Alumni Association"), translation workshops (an active form of training which stimulates creative research activities in future translators and involves creating a new translation product in the process of educational interaction between the participants in the process) (Popova, 2016, p. 86).

According to S. Danyliuk, the introduction of Internet technologies in philological education has some disadvantages. They can be explained by the fact that, in the process of developing professional competency in future philologists, these technologies require that: a) each philology student should be provided with access to a multimedia PC; b) special equipment (a multimedia complex); c) significant financial and time investments; d) a large number of learning tasks now that multimedia technologies represent a richer information environment; e) desktop access to technical support, in particular on corporate networks; e) high-quality connection; e) a methodology for using multimedia technologies in education; g) the necessary technical support; presentation equipment for independent study of educational material by philology students and teachers; cultivation of learning culture. Besides, the disadvantages of using multimedia technologies in the educational process include one's inability to express one's attitude or follow the rules of public conduct, as well as some difficulties in perceiving information from the screen and the lack of Ukrainianspeaking multimedia programmes (Danyliuk, 2013, p. 180-181).

Research activities form an integral part of professional training of philologists since they teach philology students to search methods, enlarge their research experience, motivate them to be autonomous and creative, develop their intellectual skills and personal and professional self-determination. The Encyclopedia of Education defines it as "an important component of the educational process, an organic component of education, the basic element and the driving force behind its development" (Entsyklopediia osvity, 2018, p. 554). At universities, research activities cover two areas: educational research and scientific research, which correlate with the relevant years of higher education study. Researchers view educational research as an integral part of the educational process, which "encompasses all types of educational activities and is realized through the smooth introduction of elements of scientific research during lectures, practical classes, as well as while working on term-papers, master dissertations (Mishenina, URL : http://ddpu.drohobych.net/ pedagogics/arhiv/29_ch3_2014/ 13.pdf.; Proshkin, 2009, p. 115). Such work is aimed at mastering research methods and comprehending the logic of the research process.

O. Semenoh believes that the main goals of educational research of philology students are to develop their scientific outlook and assist them in mastering research methodology and methods. Its effectiveness depends on the coordination of all components of the professional training system, the focus of the students' needs and motivation towards research during 
all years of study and both personality and activity-oriented approaches towards learning. Educational research takes place at the optimal ratio of generative and creative tasks, individual and collective forms of the educational process organization, as well as the active implementation of joint creative activities in lessons (Semenoh, 2005, p. 211). Masters dissertations present the results of the student's scientific research and are reviewed by the scientific supervisor. The topics of masters dissertations should correspond to the areas of scientific research conducted by teaching staff from a respective university department. Below are typical topics of masters dissertations in the field of translation:

- terminological innovations in the field of computer engineering (based on English-Ukrainian translations of scientific and technical texts);

- lexical, semantic and structural features of English scientific and technical multi-component terms in Ukrainian translations (based on materials in the fields of aviation, metrology and chemistry);

functions of biblical expressions in spoken and media languages, as well as characteristics of their translation (based on English and Ukrainian);

- semantic and pragmatic features of verbal and non-verbal signs in the advertising discourse (based on English-Ukrainian translation of press advertising);

- an axiological potential of reactive statements in dialogic discourse (based on English and Ukrainian)

An important component of professional training of future philologists is the practical training, which ensures the effectiveness of the acquired translation knowledge and skills, cultivates the awareness of the need to improve professional competency, strengthen confidence in the correct choice of the profession and promotes the cultural development of future philologists. As a pedagogical category, "practice / professional practice" is part of the educational process at universities. It aims to teach philology students to creatively use scientific and theoretical knowledge and practical skills in their professional activities (Entsyklopediia osvity, 2008, p. 647). Future translators traditionally engage in the following types of practical training: translation practice, information-and-analytical practice, translation assistant practice, pre-graduation practice. The content and sequence of practical training are specified in practice programmes developed by relevant departments. At each level of practical training, these programmes offer recommendations on the types and forms of assessment of the knowledge, abilities and skills students need to acquire. According to $\mathrm{N}$. Kolesnychenko, practical training of Romance and Germanic philologists can be characterized by formalism, outdated forms and methods. This is evidenced by the lack of modern international and national centres (state institutions, private translation agencies, offices) designed for linguistic, literary and translation-related practical training, as well as the lack of specialists in intercultural communication and mentor translators specializing in different types of technology, translation, media (Kolesnychenko, 2014, p. 130).

Professional competency of future philologists (translators) during their practical activities can be developed more effective if this process is corrected and supplemented by relevant modern teaching, methodological and information support.

Therefore, the justified organizational and didactic principles of professional training of philologists at Ukrainian universities prove the need to update the content of such training and introduce effective teaching forms and methods, which can cultivate the subject-subject interaction in the educational process, promote personality development and enhance the quality of education.

\section{СПИСОК ЛІТЕРАТУРА}

Данилюк, С. С. (2013). Використання Інтернет-технологій в освітньому процесі: формування професійної компетентності майбутніх філологів. Черкаси : видавець Чабаненко Ю. А.

Енциклопедія освіти. (2008).
Київ : Юрінком Інтер.

Інформаційна система "Конкурс". Вступна кампанія 2016. Взято 3 http://vstup.info.

Колесниченко, Н. Ю. (2014). Концептуальна модель організації професійної підготовки бакалаврів романо-германської філології на засадах кар'єрозорієнтованого підходу. Наукові записки Бердянського державного педагогічного університету, 3, 127-134.

Мартинюк, О. В. (2010). Професійна підготовка перекладачів у контексті глобалізаційних та інтеграційних процесів. Педагогічний дискурс, 7, 157-161.

Міщеніна, Т. (2014). Формування дослідницької компетенції майбутніх учителів філологічних спеціальностей. Взято $3 \mathrm{http}: / /$ ddpu.drohobych.net/ pedagogics/ arhiv/29_ch3_2014/13.pdf.

Про затвердження Переліку спеціалізацій підготовки здобувачів вищої освіти ступенів бакалавра та магістра за спеціальністю 035 "Філологія", за якими здійснюється формування та розміщення державного замовлення. Наказ Міністерства освіти і науки № 567 від 25.05.2016. Взято $3 \mathrm{http}: / /$ zakon2.rada.gov.ua/laws/show/ z0825-16.

Попова, О. 2016. Педагогічні умови професійно-мовленнєвої підготовки майбутніх перекладачів китайської мови в умовах університетської освіти. Науковий вісник Південноукраӥнського національного педагогічного університету імені К. Д. Уиинського, 5 (112), $83-$ 88.

Проекти стандартів вищої освіти. Взято $3 \mathrm{http}: / /$ mon.gov.ua/ activity/education/reforma-osviti/ n a u kovo-metodichna-radaministerstva/proekti-standartivvishhoyi-osviti.html.

Прошкін, В. В. (2009). Основні підходи до визначення поняття "науково-дослідна робота студентів". Наукова скарбниия освіти Донеччини, 2 (5), 114-117.

Рогульська, О. О. (2010). Педагогічні умови формування професійної компетентності майбутніх перекладачів засобами сучасних інформаційних технологій. (Автореф. дис. ... канд. пед. наук). Вінниця.

Семеног, О. М. (2005). Професійна підготовка майбутніх учителів української мови і літератури. 
Суми : ВВП "Мрія-1" ТОВ.

Скиба, К. М. (2010). Психологічні особливості організації навчальної діяльності майбутніх перекладачів, наближеної до професійної. Збірник наукових пращьь, 53, 223-225.

Чередниченко, О. І. (2007). Складові професійної компетенції письмового та усного перекладача. Вісник Київького національного університету імені Тараса Шевченка, 41, 2527.

Черноватий, Л. М. (2010). Навчально-методичний комплекс для підготовки перекладачів з англійської мови. Наукові записки, 89 (1), 5-11.

\section{REFERENCES}

Danyliuk, S. S. (2013). Vykorystannia Internet-tekhnolohii v osvitnomu protsesi: formuvannia profesiinoi kompetentnosti maibutnikh filolohiv. Cherkasy: vydavets Chabanenko Yu. A.

Entsyklopediia osvity. (2008). Kyiv : Yurinkom Inter.

Informatsiina systema "Konkurs". Vstupna kampaniia 2016. Retrieved from http://vstup.info.

Kolesnychenko, N. Yu. (2014). Kontseptualna model orhanizatsii profesiinoi pidhotovky bakalavriv romano-hermanskoi filolohii na zasadakh kar'ierozoriientovanoho pidkhodu. Naukovi zapysky Berdianskoho derzhavnoho pedahohichnoho universytetu, 3 ,
127-134.

Martyniuk, O. V. (2010). Profesiina pidhotovka perekladachiv u konteksti hlobalizatsiinykh ta intehratsiinykh protsesiv. Pedahohichnyi dyskurs, 7, 157-161.

Mishchenina, T. Formuvannia doslidnytskoi kompetentsii maibutnikh uchyteliv filolohichnykh spetsialnostei. Retrieved from http:/ /ddpu.drohobych.net/ pedagogics/ arhiv/29_ch3_2014/13.pdf.

Pro zatverdzhennia Pereliku spetsializatsii pidhotovky zdobuvachiv vyshchoi osvity stupeniv bakalavra ta mahistra za spetsialnistiu 035 "Filolohiia", za yakymy zdiisniuietsia formuvannia ta rozmishchennia derzhavnoho zamovlennia. Nakaz Ministerstva osvity i nauky № 567 vid 25.05.2016. Retrieved from http:// zakon2.rada.gov.ua/laws/show/ z0825-16.

Popova, O. (2016). Pedahohichni umovy profesiino-movlennievoi pidhotovky maibutnikh perekladachiv kytaiskoi movy $\mathrm{v}$ umovakh universytetskoi osvity. Naukovyi visnyk Pivden no ukrains $k$ oho natsionalnoho pedahohichnoho universytetu imeni $K . \quad D$. Ushynskoho, 5 (112), 83-88.

Proekty standartiv vyshchoi osvity. Retrieved from http:// mon.gov.ua/activity/education/ reform a - os viti/n a u kovo- metodichna-rada-ministerstva/ proekti-standartiv-vishhoyiosviti.html.

Proshkin, V. V. (2009). Osnovni pidkhody do vyznachennia poniattia "naukovo-doslidna robota studentiv". Naukova skarbnytsia osvity Donechchyny, 2 (5), 114-117.

Rohulska, O. O. (2010). Pedahohichni umovy formuvannia profesiinoi kompetentnosti maibutnikh perekladachiv zasobamy suchasnykh informatsiinykh tekhnolohii. (Avtoref. dys.... kand. ped. nauk). Vinnytsia.

Semenoh, O. M. (2005). Profesiina pidhotovka maibutnikh uchyteliv ukrainskoi movy i literatury. Sumy: VVP "Mriia-1" TOV.

Skyba, K. M. (2010). Psykholohichni osoblyvosti orhanizatsii navchalnoi diialnosti maibutnikh perekladachiv, nablyzhenoi do profesiinoi. $Z b$. nauk. prats, 53, 223-225.

Cherednychenko, O. I. (2007). Skladovi profesiinoi kompetentsii pysmovoho ta usnoho perekladacha. Visnyk Kyivskoho natsionalnoho universytetu imeni Tarasa Shevchenka, 41, 25-27.

Chernovatyi, L. M. (2010). Navchalno-metodychnyi kompleks dlia pidhotovky perekladachiv z anhliiskoi movy. Naukovi zapysky, 89 (1), 5-11.

Стаття надійшла 25.03.2020 p. 